\title{
REPRODUCTIVE PARAMETERS AND LONGEVITY OF Gryon gallardoi (BRETHES) (HYMENOPTERA: SCELIONIDAE) PARASITIZING Spartocera dentiventris (BERG) (HEMIPTERA: COREIDAE) EGGS
}

\author{
CANTO-SILVA, C. R. ${ }^{1}$, ROMANOWSKI, H. P. ${ }^{1}$ and REDAELLI, L. R. ${ }^{1,2}$ \\ ${ }^{1}$ PPG Biologia Animal, UFRGS, Av. Bento Gonçalves, 9500, CEP 91501-970, Porto Alegre, RS, Brazil \\ ${ }^{2}$ Departamento de Fitossanidade, UFRGS, Av. Bento Gonçalves, 7712, CEP 91540-000, Porto Alegre, RS, Brazil \\ Correspondence to: Célson Roberto Canto Silva, Universidade Estadual do Rio Grande do Sul - UERGS, \\ Unidade Cachoeira do Sul, Rua Sete de Setembro, 1040, Centro, Cachoeira do Sul, RS, Brazil, \\ e-mail: cantosilva@ig.com.br \\ Received September 30, 2003 - Accepted December 19, 2003 - Distributed February 28, 2006
}

(With 3 figures)

\begin{abstract}
The fecundity, daily progeny and longevity of Gryon gallardoi (Brethes) (Hym.; Scelionidae) were determined under laboratory conditions, using Spartocera dentiventris (Berg) (Hem.; Coreidae) eggs as host. Nineteen G. gallardoi females and 34 males were reared at $25 \pm 1{ }^{\circ} \mathrm{C}$, with a $12 \mathrm{~h}$ photophase, fed on a $10 \%$ aqueous honey solution and provided with 25-30 S. dentiventris eggs daily. The average preoviposition period was $1.3 \pm 0.35$ days, although some females began laying from the day of emergence. On average, oviposition lasted for $10.1 \pm 1.74$ days, reaching a peak on the second day, with $67.5 \pm 11.29$ eggs laid. The post-oviposition period was short ( $2.4 \pm 0.48$ days). G. gallardoi females lived significantly longer than males: $13.7 \pm 1.94$ and $10.6 \pm 1.78$ days, respectively. The overall sex ratio was 0.79 . The results reported here on the reproductive capability of the species suggest it may have a good potential as an agent for the control of $S$. dentiventris.
\end{abstract}

Keywords: insecta, tobacco, gray-tobacco-bug, parasitoid.

\section{RESUMO}

\section{Parâmetros reprodutivos e longevidade de Gryon gallardoi (Brethes) (Hym.; Scelionidae) parasitando ovos de Spartocera dentiventris (Berg) (Hem.: Coreidae)}

\begin{abstract}
A fecundidade, a produção diária de prole e a longevidade de Gryon gallardoi (Brethes) (Hym.; Scelionidae) foram determinadas em condições de laboratório, utilizando-se ovos de Spartocera dentiventris (Berg) (Hem.; Coreidae) como hospedeiro. Dezenove fêmeas e 34 machos de G. gallardoi foram acompanhados ao longo de sua vida a $25 \pm 1{ }^{\circ} \mathrm{C}$, com fotofase de $12 \mathrm{~h}$, recebendo solução aquosa de mel a $10 \%$ como alimento e grupos de 25 a 30 ovos de $S$. dentiventris para serem parasitados. O período médio de préoviposição foi 1,3 $\pm 0,35$ dias, sendo que fêmeas foram capazes de ovipositar já no dia de sua emergência. Foi observado um período médio de oviposição de 10,1 $\pm 1,74$ dias, com o pico de oviposição no segundo dia, sendo depositados ao longo dos dias uma média de 67,5 $\pm 11,29$ ovos. O período de pós-oviposição foi curto (2,4 $\pm 0,48$ dias). Fêmeas de G. gallardoi foram significativamente mais longevas que os machos, vivendo, respectivamente, $13,7 \pm 1,94$ e 10,6 $\pm 1,78$ dias. A razão sexual total observada foi de 0,79 . Os resultados aqui registrados sobre a capacidade reprodutiva da espécie sugerem que esta apresenta um bom potencial como um agente para o controle de $S$. dentiventris.
\end{abstract}

Palavras-chave: insecta, fumo, percevejo-cinzento-do-fumo, parasitóide. 


\section{INTRODUCTION}

The gray-tobacco-bug, Spartocera dentiventris (Berg) (Hem.: Coreidae), is a species associated with tobacco crops in Rio Grande do Sul, Brazil. The species cause losses resulting from the curling and withering of the attacked leaves (Costa, 1941; Schaefer \& Panizzi, 2000). Parasitism is the main mortality factor acting on eggs of the bug and may reach rates close to $50 \%$ in the field (Santos et al., 2001). Among the species of parasitoids responsible for such losses, Gryon gallardoi (Brethes) (Hym.: Scelionidae) is the most abundant, suggesting it may be a useful biological control agent.

Knowledge of the reproductive capacity of natural enemies is fundamental for the evaluation of a biological control agent's potential (Jervis \& Kidd, 1996). Moreover, studies of the factors that influence this reproductive capacity are equally important. The relation between longevity and potential fecundity indirectly influences the actual fecundity of individuals, since the females may die before laying all their eggs. Parameters may be generated by studying the longevity and fecundity of species, which make it possible not only to compare the effectiveness of different natural enemies but also to build models that allow for more sophisticated analyses of this interaction.

The genus Gryon is composed of species associated mostly to coreid bugs, many of which are pests of important crops in the northern hemisphere, Africa and Asia (Nechols et al., 1989; Asante et al., 2000; Romeis et al., 2000). In Brazil, G. gallardoi is cited as a natural enemy of coreids, attacking several cultivated and non-cultivated plants (Loiacono, 1980; Becker \& Prato, 1982; De-Souza \& Amaral-Filho, 1999). However, little is known about its role in the control of these species. Many biological and ecological studies of these species have been carried out recently in an attempt to understand the interaction between S. dentiventris and G. gallardoi on tobacco and to evaluate the use of this natural enemy as a control agent for the bug (Caldas et al., 1999; Canto-Silva, 2003; Wiedemann et al., 2003). Thus, the present work aimed to assess the reproductive biology and the longevity of $G$. gallardoi parasitizing S. dentiventris eggs.

\section{MATERIAL AND METHODS}

The present study was developed in the "Departamento de Fitossanidade, Faculdade de Agronomia, Universidade Federal do Rio Grande do Sul (UFRGS)", Porto Alegre ( $30^{\circ} 01^{\prime} \mathrm{S} 51^{\circ} 13^{\prime} \mathrm{W}$ ), RS, Brazil, from November 2000 to February 2001. G. gallardoi was reared in the laboratory from S. dentiventris parasitized eggs collected from a tobacco crop in the field. The parasitoids were kept in $500 \mathrm{ml}$ transparent plastic bottles containing S. dentiventris eggs, sealed with cotton wool and kept at $25 \pm 1{ }^{\circ} \mathrm{C}$, with a $12 \mathrm{~h}$ photophase. The parasitoids were fed daily ad libitum on a $10 \%$ aqueous honey solution. Non-parasitized $S$. dentiventris eggs were obtained from an experimental tobacco crop (type Virginia, var. k326), where $S$. dentiventris females were kept on the plants in voile fabric cages for the exclusion of parasitism.

In the laboratory, an experiment was carried out under the same breeding conditions. Newly emerged G. gallardoi couples ( $<4 \mathrm{~h}$ old) were confined in $500 \mathrm{~mL}$ transparent plastic bottles containing food and about 25-30 freshly laid S. dentiventris eggs ( $<$ one day old). These eggs were kept on the part of the plant where they had been laid in order to minimize manipulation. The eggs were removed and substituted for a new group of non-parasitized eggs daily until the parasitoid female died. The eggs exposed to parasitism were then reared under the same conditions until their fate could be determined. When parasitoids emerged, they were sexed and counted. Eggs still remaining after a week elapsed since the last emergence were dissected to check their content.

For the analysis of fecundity and longevity, only females that had effectively produced offspring were considered. Individuals whose death was caused by accidental factors - such as injury due to manipulation or drowning in drops of the solution used as food - were excluded from the analysis. Individuals were kept in couples all the time so that, whenever a parasitoid died, it was replaced by other of the same sex. All handling of parasitoids was conducted with the use of $\mathrm{CO}_{2}$. Based on these criteria, the results obtained correspond to the follow-up of 19 G. gallardo $i$ females and 34 males.

The findings of male and female longevity were compared by the Mann-Whitney test (Sokal 
\& Rohlf, 1981) and the averages are presented together with their standard error.

\section{RESULTS AND DISCUSSION}

The average longevities of $G$. gallardoi males and females were $10.6 \pm 1.78$ and $13.7 \pm 1.94$ days, respectively (Table 1 ). The values recorded were highy variable for both sexes, with modes on 1 to 5 days for males and on 6 to 10 days for females (Fig. 1). Females lived significantly longer than males $(\mathrm{Z}(\mathrm{u})=2.15 ; \mathrm{p}=0.0314)$. Maximum longevities recorded were 40 and 32 days for males and females, respectively (Table 1). G. gallardoi longevity was lower than described for other species of the genus. Asante et al. (2000), studying the efficiency of Gryon fulviventris (Crawford), a parasitoid of the eggs of the coreid Clavigralla tomentosicollis Stal in Nigeria, found an average longevity of $34.29 \pm 0.5$ days (laboratory conditions: $27 \pm 1{ }^{\circ} \mathrm{C}, 50-80 \%$ relative humidity, $50 \%$ aqueous honey solution diet, no hosts offered). Studies carried out in the central region of the USA with Gryon pennsylvanicum (Ashmead), an egg parasitoid of Anasa tristis DeGeer (Hemiptera: Coreidae), reported an average longevity of

TABLE 1

Reproductive parameters and longevity of Gryon gallardoi parasitizing Spartocera dentiventris eggs, reared at $25 \pm 1^{\circ} \mathrm{C}$ and a 12 h photophase, fed on a $10 \%$ aqueous honey solution.

\begin{tabular}{|l|c|c|c|}
\hline \multicolumn{1}{|c|}{ Parameter } & n & Mean \pm SE & Range \\
\hline Male longevity (days) & 34 & $10.6 \pm 1.78$ & $2-40$ \\
\hline Female longevity (days) & 19 & $13.7 \pm 1.94$ & $5-32$ \\
\hline \% of eggs parasitised/female & 19 & $19.3 \pm 1.81$ & $2.86-35.92$ \\
\hline Pre-oviposition period (days) & 19 & $1.3 \pm 0.35$ & $0-6$ \\
\hline Oviposition period (days) & 19 & $10.1 \pm 1.74$ & $0-6$ \\
\hline Post-oviposition period (days) & 19 & $2.4 \pm 0.48$ & $8-173$ \\
\hline Progeny/female & 19 & $67.5 \pm 11.29$ & $12.5-38.18$ \\
\hline Male progeny/female (\%) & 19 & $20.3 \pm 1.49$ & - \\
\hline Overall Sex ratio & 1260 & 0.79 & 2 \\
\hline
\end{tabular}

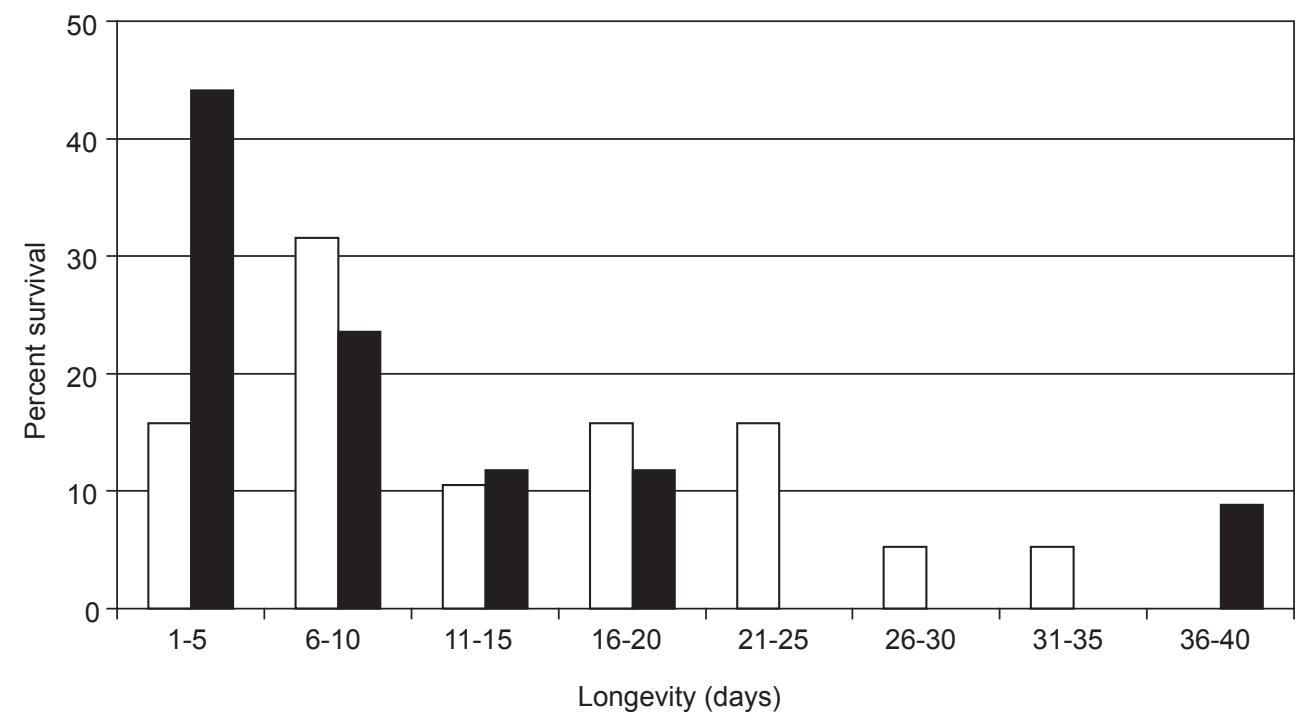

Fig. 1 - Percent survival of male (black blocks) and female (white blocks) Gryon gallardoi parasitizing Spartocera dentiventris eggs, reared in the laboratory at $25 \pm 1{ }^{\circ} \mathrm{C}$ and a $12 \mathrm{~h}$ photophase, fed on a $10 \%$ aqueous honey solution and provided with hosts. 
$39.2 \pm 12.4$ days (laboratory conditions: $27 \pm 1{ }^{\circ} \mathrm{C}$, $75 \%$ relative humidity, $40 \%$ aqueous honey solution diet, hosts offered) (Nechols et al., 1989). An even higher value was obtained by Romeis et al. (2000) for Gryon clavigrallae Mineo parasitizing Clavigralla scutellaris Spinola and C. gibossa (Westwood) (Hemiptera: Coreidae) in India: 55.0 \pm 3.30 days for females and $28.8 \pm 5.34$ days for males (laboratory conditions: $25 \pm 1{ }^{\circ} \mathrm{C}, 50 \pm$ $10 \%$ relative humidity, non-diluted honey diet, no hosts offered). However, the lower longevity of G. gallardoi when compared with the abovelisted species must be considered carefully since experimental conditions vary substantially between studies.

On average, approximately $19 \%$ of the eggs offered to the females during their lives were parasitized (Table 1). G. gallardoi females can start laying on the day they emerge, although only $32 \%$ of them did so. An average pre-oviposition period of $1.3 \pm 0.35$ days was observed (Table 1). On average, females laid for $10.1 \pm 1.74$ days about $67.5 \pm 11.29$ eggs (Table 1), distributed throughout most of the observed oviposition period. G. gallardoi fecundity is similar to that recorded for G. pennsylvanicum $(71.8 \pm 23.1$ eggs; Vogt \& Nechols, 1993) and higher than that found for G. clavigrallae $(56.4 \pm 4.4$ eggs; Romeis et al., 2000). When compared with the fecundity of other Scelionidae, it lies on an intermediate level. For Trissolcus basalis (Wollaston), a classical Nezara viridula (L.) (Pentatomidae) biological control agent, Awan et al. (1990) reported 233.7 eggs in California, USA, while Corrêa-Ferreira \& Zamataro (1989) obtained $250.4 \pm 52.2$ eggs in southern Brazil. On the other hand, studies on the scelionids Telonomus podisi Ashmead, Trissolcus euschisti (Ashmead) (Yergan, 1982) and Telonomus cristatus Johnson (Orr \& Boethel, 1990) parasitizing Podisus maculiventris (Say) (Hem.; Pentatomidae) eggs showed reproductive potentials lower than the one obtained for $G$. gallardoi $(39.6 \pm 4.50,63.7 \pm 6.90$ and $32.2 \pm 1.80$ eggs, respectively)

Parasitoid fecundity can reflect the abundance or ease with which hosts can be found (Price, 1974); hence, the above mentioned differences in fecundity may relate to the average size of the groups of eggs or egg clusters of the attacked hosts. In fact, both $P$. maculiventris and $S$. dentiventris lay groups with few eggs, i.e., on average 18.7 (Orr et al., 1986) and 23.9 eggs, respectively (Caldas et al., 2000). In contrast, $N$. viridula parasitized by T. basalis lays clusters of approximately 100 eggs on average (Costa, 1996).

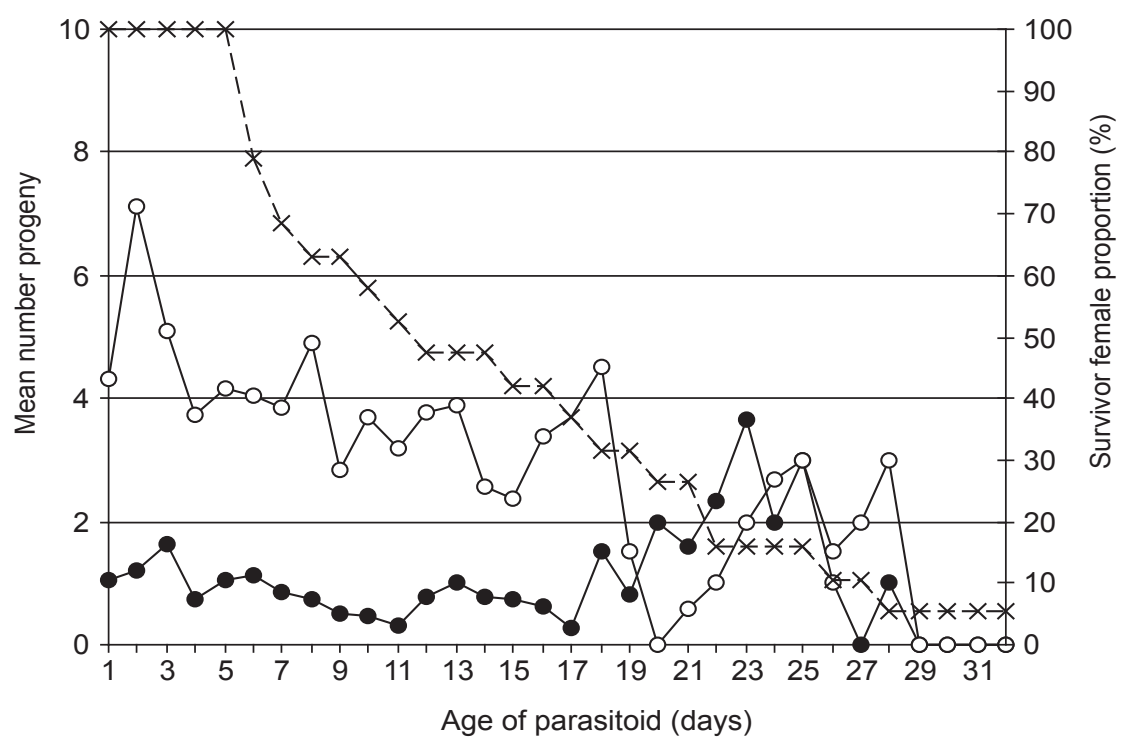

Fig. 2 - Influence of Gryon gallardoi age on the production of male (black circles) and female (white circles) progeny and female survival proportion (\%) under laboratory-controlled conditions $\left(25 \pm 1{ }^{\circ} \mathrm{C}\right.$ and $12 \mathrm{~h}$ photophase, fed on a $10 \%$ aqueous honey solution). 
The production of female offspring per day peaked on the second day of life $(7.1 \pm 1.76$ eggs, thereafter declining with the females' age (Fig. 2). This pattern, with an oviposition peak on the second or third day of life, is widespread not only among species of Gryon (Nechols et al., 1989; Romeis et al., 2000), but also among other genera of the Scelionidae (Powell \& Shepard, 1982; Yergan, 1982; Corrêa-Ferreira \& Zamataro, 1989). Male offspring were relatively constant along the parasitoid life, increasing slightly towards the end of the oviposition period of the long-living females (Fig. 2). The same finding was reported by Corrêa-Ferreira \& Zamataro (1989) for T. basalis females over 4 days (Australian breed) or 7 days old (native breed).

An analysis of the pooled offspring indicated that all the females produced an excess of females: only $20.3 \pm 1.49 \%$ of the offspring was male and the overall sexual ratio was 0.79 (Table 1).

Longer-living females oviposited more. Regression of the number of offspring versus female longevity showed a significantly positive relation $\left(y=4.9464 x-0.1061 ; r^{2}=0.68 ; p=0.0001\right.$; Fig. 3), suggesting a high reproductive potential for the species, though strongly counteracted by the accomplished longevity. The maximum oviposition period recorded was 28 days (173 eggs). This long oviposition period associated with a short postoviposition period ( $2.4 \pm 0.48$ days on average, Table 1), suggests a reproductive strategy typical of synovigenic parasitoids, i.e., oocytes developing gradually along the lifespan. One may speculate that the long oviposition period of G. gallardoi is an adaptation to the similarly long $S$. dentiventris oviposition period (approximately 48 days; Caldas et al., 1999). Such a strategy would enable the parasitoid to have its reproduction synchronized with the seasonal availability of its host.

Comparisons of biological parameters obtained from laboratory studies are constrained by the variety of experimental conditions of the studies. The results reported here indicate that the magnitude of the species' fecundity is similar to that observed for other species used in biological control. The abundance of $G$. gallardoi in the system studied may be explained, at least in part, by such fecundity. This pattern indicates the good potential of the species as a biocontrol agent of $S$. dentiventris populations. The actual efficiency of G. gallardoi control depends on several factors that can act upon its fecundity in the field and on its effectiveness to locate and parasitize its host. Such aspects have been also investigated and the resulting analysis will be the subject of forthcoming papers.

Acknowledgments - The authors thank the Departamento de Fitossanidade, Faculdade de Agronomia - Universidade Federal do Rio Grande do Sul for the use of its facilities in the development of this study. Thanks are also due to Dra. Beatriz S. Corrêa-Ferreira for information and bibliography. Contribution $\mathrm{n}^{\circ} 416$ of the Department of Zoology, Postgraduate Program in Animal Biology, Instituto de Biociências, UFRGS.

\section{REFERENCES}

ASANTE, S. K., JACKAI, E. N. \& TAMO, M., 2000, Efficiency of Gryon fulviventris (Hymenoptera: Scelionidae) as na egg parasitoid of Clavigralla tomentosicollis (Hemiptera: Coreidae) in northern Nigeria. Environ. Entomol., 29(4): 815-821.

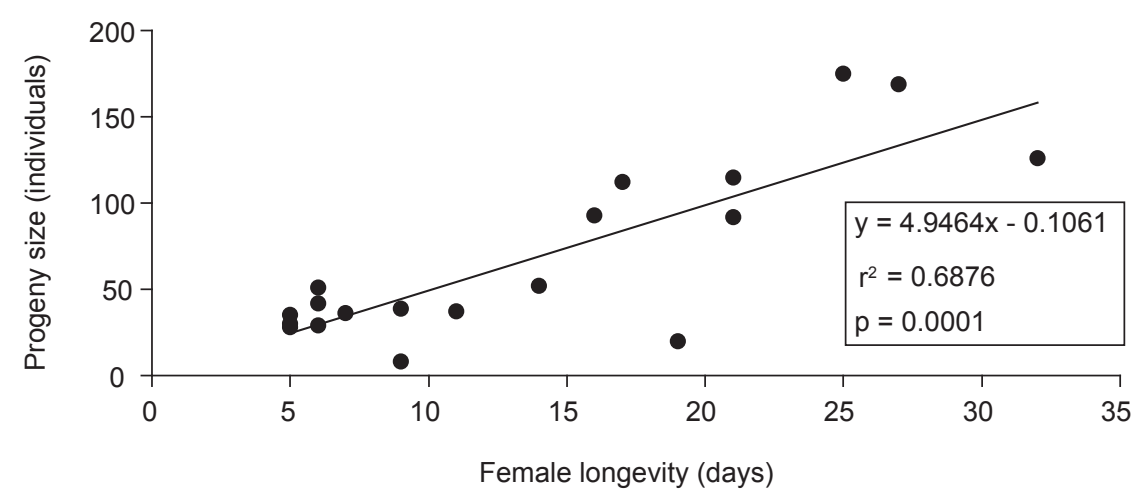

Fig. 3 - Female longevity and progeny of Gryon gallardoi on Spartocera dentiventris eggs in the laboratory, at $25 \pm 1{ }^{\circ} \mathrm{C}$ and a $12 \mathrm{~h}$ photophase, fed on a $10 \%$ aqueous honey solution. 
AWAN, M. S., WILSON, L. T. \& HOFFMANN, M. P., 1990, Comparative biology of three geographic populations of Trissolcus basalis (Hym.: Scelionidae). Environ. Entomol., 19(2): 387-392.

BECKER, M. \& PRATO, M. D., 1982, Natality and natural mortality of Spartocera lativentris Stal, 1870 (Heteroptera: Coreidae) in the egg stage. An. Soc. Entomol. Brasil, 11: 269-281.

CALDAS, B-H. C., REDAELLI, L. R. \& DIEFENBACH, L. M. G., 1999, Parâmetros Reprodutivos de Corecoris dentiventris Berg (Hemiptera, Coreidae) em Cultura de Fumo (Nicotiana tabacum). An. Soc. Entomol. Brasil, 28(4): 595-600.

CALDAS, B.-H. C., REDAELLI, L. R. \& L. M. G. DIEFENBACH, 2000, Biology of Corecoris dentiventris Berg, 1884 (Hemiptera: Coreidae) in tobacco culture (Nicotiana tabacum). Rev. Bras. Biol., 60: 173-178.

CANTO-SILVA, C. R., 2003, Parâmetros bioecológicos de Gryon gallardoi (Brethes) (Hymenoptera: Scelionidae) e modelagem da dinâmica espaço-temporal da sua interação com Spartocera dentiventris (Berg) (Hemiptera: Coreidae) através da simulação de múltiplos agentes. Tese de doutorado, Universidade Federal do Rio Grande do Sul, Programa de Pós-Graduação em Biologia Animal, Instituto de Biociências, Porto Alegre, 210p.

CORRÊA-FERREIRA, B. S. \& ZAMATARO, C. E. O., 1989, Capacidade reprodutiva e longevidade dos parasitóides de ovos Trissolcus basalis (Wollaston) e Trissolcus mitsukurii Ashemead (Hymenoptera: Scelionidae). Rev. Brasil. Biol., 49(2): 621-626.

COSTA, J. A., 1996, Cultura da soja. Ed. Ivo Manica e José Antônio Costa, Brasil, 233p.

COSTA, R. G., 1941, Pragas de plantas cultivadas no Rio Grande do Sul. Porto Alegre, Secretaria da Agricultura, $136 \mathrm{p}$.

DE-SOUZA, C. E. P. \& AMARAL-FILHO, B. F., 1999, Ocorrência natural de parasitóides de Leptoglossus zonatus (Dallas) (Heteroptera: Coreidae). An. Soc. Entomol. Brasil, 28(4): 757-759.

JERVIS, M. \& KIDD, N., 1996, Insect Natural Enemies: practical approaches to their study and evaluation. Chapman \& Hall, London, 491p.

LOIACONO, M. S., 1980, Nota sobre tres Scelionidos parasitoides de hemipteros de la República argentina y Brasil (Hymenoptera-proctotrupoidea). Rev. Soc. Ent. Argentina, 39 (3-4): 173-178.
NECHOLS, J. R., TRACY, J. L. \& VOGT, E. A., 1989, Comparative ecological studies of indigenous egg parasitoids (Hymenoptera; Scelionidae, Encyrtidae) of the sguash bug, Anasa tristis (Hemiptera: Coreidae). J. Kansas Entomol. Soc., 62(2): 177-188.

ORR, D. B. \& BOETHEL, D. J., 1990, Reproductive Potential of Telenomus cristatus and T. podisi (Hymenoptera: Scelionidae), Two Egg Parasitoids of Pentatomids (Heteroptera). Ann. Entomol. Soc. Am., 83(5): 902-905.

ORR, D. B., RUSSIN, J. S., BOETHEL, D. J. \& JONES, W. A., 1986, Stink bug (Hemiptera: Pentatomidae) egg parasitism in Louisiana soybean. Environ. Entomol., 15: 1250-1254.

POWELL, J. E. \& SHEPARD, M., 1982, Biology of Australian and United States strains of Trissolcus basalis, a parasitoid of green vegetable bug, Nezara viridula. Aust. J. Ecol., 7: 181-186.

PRICE, P. W., 1974, Strategies for egg production. Evolution, 28: $76-84$

ROMEIS, J., SHANOWER, T. G. \& MADHURI, K., 2000, Biology and field performance of Gryon clavigrallae (Hymenoptera: Scelionidae), an egg parasitoid of Clavigralla spp. (Hemiptera: Coreidae) in India. Bull. Entomol. Res., 90: 253-263.

SANTOS, R. S. S., REDAELLI, L. R. \& DIEFENBACH, L. M. G., 2001, Ocorrência de Parasitismo em Ovos de Spartocera dentiventris (Berg) (Hemiptera: Coreidae) em Cultura de Fumo. Neotrop. Entomol., 30(4): 731-733.

SCHAEFER, C. W. \& PANIZZI, A. R., 2000, Heteroptera of Economic Importance. CRC Press, Boca Raton, Florida, USA, 856p.

SOKAL, R. R. \& ROHLF, F. J., 1981, Biometry. $2^{\text {nd }}$ ed., New York, Freeman, 859p.

VOGT, E. A. \& NECHOLS, J. R., 1993, The influence of host deprivation and host source on the reproductive biology and longevity of the squash bug egg parasitoid Gryon pennsylvanicum (Ashmead) (Hymenoptera: Scelionidae). Biol. control, 3: 148-154.

WIEDEMANN,L.M.,CANTO-SILVA, C.R., ROMANOWSKI, H. P. \& REDAELLI, L. R., 2003, Oviposition behaviour of Gryon gallardoi (Hym.; Scelionidae) on eggs of Spartocera dentiventris (Hem.; Coreidae). Braz. J. Biol., 63(1): 133-139.

YERGAN, K. V., 1982, Reproductive capability and longevity of the parasitic wasps Telonomus podisi and Trissolcus euschisti. Ann. Entomol. Soc. Am., 75(2): 181-183. 